\title{
REPRESENTASI KEBEBASAN TOKOH UTAMA \\ DALAM NOVEL TRILOGI SOEKRAM KARYA \\ SAPARDI DJOKO DAMONO \\ (TINJAUAN EKSISTENSIALISME)
}

\author{
Nouval Rumaf a,", Siti Fatihaturrahmah Al. Jumroh, \\ ${ }^{a}$ STKIP Muhammadiyah Sorong-Papua Barat \\ Jl. Kh. Ahmad Dahlan No. 01, Malawele, Aimas, Kabupaten Sorong, Papua Barat, Malawele, \\ Aimas, Sorong, Papua Barat, Indonesia \\ b STKIP Muhammadiyah Sorong-Papua Barat \\ J1. Kh. Ahmad Dahlan No. 01, Malawele, Aimas, Kabupaten Sorong, Papua Barat, Malawele, \\ Aimas, Sorong, Papua Barat, Indonesia \\ *ovha12015@gmail.com
}

\begin{abstract}
Abstrak: Penelitian ini bertujuan mendeskripsikan representasi kebebasan tokoh utama dalam novel Trilogi Soekram karya Sapardi Djoko Damono. Penelitian ini menggunakan pendekatan kualitatif, sedangkan metode penelitian menggunakan metode deskriptif. Hasil penelitian ini terdiri atas dua wujud kebebasan yaitu: (a) kebebasan dalam wujud perkataan dan (b) kebebasan dalam wujud perbuatan. Kebebasan dalam wujud perkataan merupakan ujaran tokoh utama Soekram yang menggugat pengarang, untuk mempertanyakan keberadaan dirinya di dalam cerita., sedangkan kebebasan dalam wujud perbuatan merupakan tingkah laku tokoh utama Soekram yang merasa cemas dan keluar dari hal-hal yang membatasi dirinya untuk menemukan eksistensinya di dalam cerita.
\end{abstract}

Kata Kunci: Representasi, Kebebasan, Eksistensi

Abstract: The purpose of this study is to explain representation freedom of the main character in the novel Trilogi Soekram by Sapardi Djoko Damono. This study made use of qualitative approach with a descriptive method. As results, this study revealed two forms of freedom, that are (a) freedom in a form of speech and (b) freedom in a form of deed. The freedom in the form of speech is indicated from the speech of the main character, Soekram, who indicted the author to question his existence in the story; meanwhile, the freedom in the form of deed is seen through the conduct of the main character, Soekram, who feels anxious and goes beyond his limits him to find his existence in the story.

Keyword: Representation, Freedom, Existence

\section{PENDAHULUAN}

Karya sastra merupakan bentuk pembebasan yang berusaha membebaskan diri dari segala macam tekanan yang datang dari dalam maupun luar. Karya sastra memuat fenomena-fenomena batin yang tampak dalam perilaku tokohtokohnya. Hal tersebut sejalan dengan pendapat
Semi (1998: 1-3) yang menyebutkan bahwa karya sastra adalah ungkapan pribadi manusia berupa pengalaman, pemikiran, perasaan, ide, semangat, dan keyakinan dalam bentuk gambar nyata, yang dapat membangkitkan pesona dengan alat bahasa yang mampu menimbulkan makna.

Jan Van Luxemburg (dalam Saifur \& Emzir, 2015: 6) menyebutkan, bahwa karya sastra 
adalah sebuah ciptaan atau kreasi. Karena karya sastra adalah kreasi, maka karya sastra bukanlah imitasi atau tiruan. Penciptaan karya sastra oleh sastrawan pada hakikatnya mampu menciptakan sebuah dunia baru. Karya sastra yang dihasilkan merupakan aktualisasi eksistensi tokoh yang direpresentasikan oleh pengarang. Tidak hanya terjadi di dunia nyata, dalam wujudnya sebagai fenomena keeksistensian manusia juga sering digunakan sebagai latar belakang cerita dalam dunia sastra.

Novel Trilogi Soekram ini merupakan karya terbaru Sapardi Djoko Damono yang diterbitkan tahun 2015. Novel tersebut merupakan gabungan dari tiga novel yang masing-masing berjudul: Pengarang Telah Mati, Pengarang Belum Mati, dan Pengarang Tak Pernah Mati.

Keunikan novel Trilogi Soekram terletak pada kebebasan tokoh utama yang menjadikan dirinya sebagai individu yang bereksistensi yaitu individu yang aktif, optimis, dan kuat. Sehingga mempertanyakan keberadaan dirinya di dalam cerita yang diabiarkan begitu saja oleh pengarang. Soekram sebagai tokoh utama memiliki kebebasan, baik bebas dalam bentuk perkataan maupun tindakan.Artinya Soekram menunjukan perihal wujud eksistensi sebagai individu yang mandiri dan tidak mudah diintervensi.

Persoalan eksistensi dalam karya sastra sangat menarik untuk dikaji, karena setiap karya sastra yang baik selalu menyajikan dan menyuguhkan soal-soal filosofis dan unsur-unsur eksistensi tokoh yang harus diinterpretasikan oleh pembaca maupun peneliti. Hal tersebut sesuai dengan pernyataan (Ahmed, 1988: 64) yang menjelaskan bahwa, karya sastra yang baik niscaya tersirat sikap filsafat tertentu, jejak-jejak filsafat tersebut cenderung berada dibalik segi kebahasaan yang berwujud kesusastraan.

Suyasa (2004: 9) menjelaskan bahwa karya sastra mempunyai andil yang cukup besar dalam menyumbangkan buah perenungan, pemikiran serta menawarkan berbagai solusi terhadap masalah-masalah yang terjadi pada manusia dalam wujud tindakan perilakunya sebagai manusia yang bereksistensi maupun sebagai manusia sosial. Manusia yang bereksistensi ialah manusia yang bebas mewujudkan dirinya secara mandiri di dalam dunia sekaligus mengatasi dunia dengan caranya secara mandiri pula.

Tinjauan eksistensi memiliki relevansi dengan gejala yang dialami tokoh utama pada novel Trilogi Soekram yang menekankan pada perasaan subjektif, pengalaman-pengalaman personal, kebebasan dalam dunia fiksi bersama tokoh-tokoh lainnya. Eksistensialisme sangat berorientasi kepada persoalan humanistik yang selalu memperhatikan pengalaman subjektif sebagai fenomena kebebasan tingkah laku manusia yang diteliti melalui karya sastra.

Pentingnya kajian eksistensi dalam karya sastra, maka penelitian dengan menggunakan kajian eksistensi telah dilakukan oleh beberapa pihak. Penelitian yang dilakukan oleh Yunus (2011), berjudul Kebebasan dalam Filsafat Eksistensialisme Jean Paul Sartre. Penelitian tersebut difokuskan pada kesadaran manusia karena manusia berhadapan dengan dunianya. Hasil penelitian berupa deskripsi mendalam mengenai kebebesan yang menjadi esensi manusia, dan manusia yang bebas selalu menciptakan dirinya, mengatur dirinya, memilih dan dapat memberi makna pada realitas.

Penelitian yang dilakukan oleh Heni (2010), berjudul Makna Hidup dalam Dinamika Eksistensi Tokoh Silas Marner: Kajian Psikologi Eksistensialiseme dalam Novel Silas Marner Karya George Eliot. Penelitian tersebut difokuskan pada dinamika eksistensi manusia yang direfleksikan oleh tokoh utamanya. Hasil penelitian berupa deskripsi mendalam mengenai makna hidup dalam tiap kondisi eksistensi tokoh utama Silas Marner yang senantiasa mencari makna hidup dan membuatnya memiliki arah dan tujuan dalam menjalani hidupnya.

Penelitian berikut dilakukan oleh Fahimsyah dkk (2013), yang berjudul Eksistensialisme dalam Novel Najla Karya Byar Rufael Sebuah Tinjauan Psikologi Humanistik. Penelitian tersebut difokuskan pada keterkaitan unsur-unsur 
yang terdapat pada novel dan analisis hubungan eksistensial dalam novel Najla. Hasil penelitian menunjukan bahwa tokoh utama mengalami kebebasan, penerimaan, atas kematian, isolasi, dan ketidakbermaknaan.

Penelitian berikut dilakukan oleh Mendrofa (2011), yang berjudul Eksistensialisme Naturalistik: Kajian Perspektif Naturalistik Terhadap Konsep Eksistensialisme Mengenai Kebebasan dan Faktisitas. Penelitian tersebut difokuskan pada manusia yang dipahami dalam kealamiahannya dan tetap bisa eksis, serta dalam kebebasan proyeksi eksistensinya. Hasil penelitian adalah pendeskripsian yang mendalam tentang eksistensi manusia secara naturalistik, dan memberikan jawaban terbaik dalam kaitannya dengan kemanusiaan.

Berdasarkan penelitian-penelitian terdahulu, penelitian yang dilakukan ini memiliki beberapa persamaan dan perbedaan. Persamaan penelitian ini dengan penelitian terdahulu terletak pada tokoh tertentu dalam novel dan kajian kebebasan dan kemanusiaan dengan menggunakan tinjauan eksistensi, sedangkan perbedaannya pada kata representasi yang tidak digunakan dalam penelitian terdahulu, tetapi digunakan dalam penelitian ini. Representasi yang dimaksud adalah bagaimana sebuah realitas kebebasan tokoh utama yang terdapat dalam novel Trilogi Soekram dapat digambarkan dan dikonstruksikan secara detail melalui media bahasa. Hal tersebut sesuai dengan pendapat Barker (2015: 9) yang menyebutkan bahwa, representasi adalah bagaimana realitas dunia dikonstruksi dan direpresentasikan secara sosial oleh manusia melalui media, baik media masa atau media cetak maupun media bahasa.

\section{METODE}

Metode dalam penelitian ini menggunakan metode kualitatif dan didukung oleh pendekatan deskriptif yang digunakan untuk mendeskripsikan data penelitian yang disajikan dalam bentuk paparan data kutipan kalimat dalam satuan cerita yang sesuai dengan tujuan penelitian. Sumber data penelitian adalah novel Trilogi Soekram karya Sapardi Djoko Damono. Data penelitian berupa kutipan-kutipan kalimat dalam satuan cerita yang mengandung unsur kebebasan perkataan dan kebebasan perbuatan. Langkahlangkah analisis data meliputi: (1) membaca secara kritis, (2) pengumpulan data, (3) penyajian data, (4) reduksi data, (5) penafsiran data, dan terakhir (6) penarikan simpulan.

\section{HASIL DAN PEMBAHASAN}

Hasil penelitian dan pembahasan ini dipaparkan secara sistematis dengan menyertakan pembahasan melalui novel yang dikaji. Hasil penelitian ini terdiri atas 2 aspek, yaitu (1) Representasi kebebasan tokoh utama Soekram dalam wujud perkataan; (2) Representasi kebebasan tokoh utama Soekram dalam wujud perbuatan.

Kebebasan merupakan kemampuan yang dimiliki manusia untuk mengembangkan serta mengarahkan hidupnya. Kemampuan tersebut, menyangkut kehendak, bahkan ciri khas kebebasan berkaitan erat dengan kenyataan bahwa manusia adalah mahluk yang berasio, jika manusia bertindak bebas, itu berarti manusia tahu apa yang diperbuatnya dan apa sebab diperbuatnya.

Bentuk kebebasan yang muncul dalam novel Trilogi Soekram karya Sapardi Djoko Damono merujuk pada pola pikir Soekram sebagai tokoh utamanya. Bentuk kebebasan dalam novel Trilogi Soekram dicirikan dengan wujud tindakan tokoh utama yang di dalamnya terdapat kondisi-kondisi yang menandai hasil dari suatu keputusan di antara alternatif-alternatif, karena esensi dari kehidupan Soekram adalah kebebasannya dan kebebasan tersebut, menjadi penentu bagi tindakan-tindakannya. Hal ini, tampak dalam kutipan dialog data pertama (D-1) sebagai berikut. 
Soekram mencoba memahami kisah itu, tetapi gagal. Seperti dalam buku cerita saja. "ibu tak pernah ke luar rumah lagi, sejak itu. Beliau merasa menjadi biang keladi kenakalan anaknya, merasa tidak bisa mendidik anak laki-lakinya. "Kenapa begitu? Kan suru yang bertanggung jawab," kata Soekram sok tahu. (Damono, 2015: 189)

Kutipan data pertama tersebut, menggambarkan bentuk kebebasan yang ditampilkan oleh tokoh utama melalui dialog dalam cerita. Data ini mengandung esensi kehidupan yang merujuk pada kebebasan perkataan Soekram yang dapat diperhatikan melalui penggalan kutipan berikut "kenapa begitu? Kan suru yang bertanggungjawab," kata Soekram sok tahu. Penggalan kutipan tersebut menggambarkan adanya bentuk sikap kebebesan perkataan tokoh utama Soekram dalam menanggapi sesuatu. Kalimat Tanya kenapa begitu? Menunjukkan adanya efek keheranan yang dimunculkan melalui proses berpikir Soekram sehingga melahirkan esensi kehidupan Soekram dalam wujud kebebasannya untuk menalar kalimat Tanya yang diutarakan sendiri tentang kisah hidupnya. Keeksistensian tokoh utama Soekram dalam kutipan ini didukung pula oleh penggalan kutipan frasa sok tau yang merupakan gabungan kata sok (berlagak) dengan kata tahu (mengerti akan sesuatu hal) yang menimbulkan efek negatif sebagai orang yang dianggap bernalar dengan logika sendiri namun kebenarannya masih diragukan.

Bentuk kebebasan tokoh utama dalam novel Trilogi Soekram juga tergambar melalui kutipan dialog (D-2) sebagai berikut.

"Datuk ..."

"Datu Maringgih, Kram, bukan Meringgih.

Mereka bersaudara."

"Dua-duannya datuk? Kok?"

Lho, Kram, kan kamu yang ngarang. Ya biar saja. (Damono, 2015: 187)
Kutipan data kedua tersebut, menggambarkan bentuk kebebasan yang ditampilkan oleh tokoh utama melalui dialog dalam cerita. Data ini mengandung esensi kehidupan yang merujuk pada kebebasan perkataan Soekram yang dapat diperhatikan melalui penggalan kutipan berikut "Ya biar saja" Penggalan kutipan tersebut menggambarkan adanya bentuk sikap kebebesan perkataan tokoh utama Soekram dalam menanggapi sesuatu dari lawan tuturnya. Soekram menunjukan keegoisannya dalam bentuk perkataan. Hal tersebut telah mencerminkan karakter dan sikap Soekram yang memiliki unsur eksistensi sebagai individu yang bebas dan tidak menerima kritikan atau saran dari orang lain. Selain itu kutipan " $y a$ biar saja" juga merupakan kata yang digunakan untuk mengukuhkan kata-kata dan maksud dari kawan bicaranya.

Soekram sebagai tokoh utama dalam novel Trilogi tersebut, menjadikan kebebasan sebagai suatu problem yang terus-menerus digeluti dan diperjuangkan. Wujud kebebasan eksistensi Soekram, tergambar dalam kutipan data dialog (D-3) sebagai berikut.

"Saya tidak menciptakan Nurbaya. Saya
adalah rekan senasibnya."
"pikiranmu kacau, Kram. Aku tidak mau
terlibat dalam kekacauan itu, sama sekali."
"Saya hanya mau mencari Nurbaya, dia dalam
bahaya dan saya harus menolongnya."
"Jangan mencari-cari yang tidak ada, Kram."
tapi dia ada. (Damono, 2015: 253).

Kutipan data ketiga tersebut, menggambarkan bentuk kebebasan yang ditampilkan oleh Soekram melalui dialog dalam cerita. Data ini mengandung esensi kehidupan yang merujuk pada kebebasan pemikiran tokoh Soekram yang dapat diperhatikan melalui penggalan kutipan berikut "Pikiranmu kacau, kram." Penggalan kutipan tersebut menggambarkan adanya sikap kebebesan pemikiran Soekram yang dianggap kacau karena Soekram ke luar dari dirinya untuk membentuk 
eksistensinya secara bebas. Soekram tidak ingin membatalkan rencanannya untuk mencari sesuatu yang belum tentu ada menurut orang lain, tetapi menurutnya sesuatu yang tidak ada itu akan menjadi ada. Hal tersebut menggambarkan sosok Soekram sebagai individu yang bereksistensi, baik bereksistensi dalam kemungkinan maupun bereksistensi dalam kenyataan, karena eksistensi dalam kemungkinan adalah keseluruhan tokoh fiksi yang dapat menyebabkan terjadinya eksistensi dalam kenyataan dan eksistensi dalam kenyataan hanya tersedia dalam saat-saat yang langkah yang didalamnya Soekram dapat ke luar dari dirinya.

Keeksistensian hidup tokoh utama dalam novel Trilogi Soekram selalu berupaya memperlihatkan kebebasannya dalam hal berbicara atau perkataan. Hal ini, dapat diperhatikan melalui kutipan data monolog (D4) sebagai berikut.

Bahwa pengarang itu meninggal dunia, apa urusannya dengan saya? Pengarang itu meninggal, titik. Dengan demikian selesailah segala tugas yang harus ditunaikannya di dunia. Bahwa cerita yang ditulisnya belum selesai, apa pula masalahnya? (Damono, 2015: 4).

Kutipan data keempat tersebut, menggambarkan bentuk kebebasan yang ditampilkan oleh tokoh utama berupa monolog dalam cerita. Data ini mengandung esensi kehidupan yang merujuk pada kebebasan perkataan Soekram yang dapat diperhatikan melalui penggalan kutipan berikut "apa urusannya dengan saya? " kutipan tersebut, menggambarkan adanya kebebesan perkataan Soekram dalam menanggapi sesuatu yang terjadi dan terkait dengan dirinya. Penggalan tersebut dikaitkan oleh Soekram sebagai bentuk ekspresi kecemasan dan kejengkelan terhadap pengarangnya yang telah meninggalkannya, kutipan tersebut menunjukkan eksistensi Soekram dalam mengambil keputusan atas kejadian yang dialami dalam cerita untuk tidak mudah terpengaruh dalam hal apapun yang mengancam dirinya. Hal tersebut yang mencirikan Soekram sebagai individu yang bereksistensi.

Keeksistensian hidup tokoh Soekram dalam novel Trilogi Soekram memunculkan respon tokoh utama atas kebebasan subjektivitasnya yang merujuk pada pembebasan nasib dirinya dari bayang-bayang doktrinasi yang selama ini menghantuinya. Soekram meyakini bahwa kebebasan subjektivitas merupakan kebenaran yang diyakini, hal tersebut yang menjadi dasar sehingga, Soekram selalu memperlihatkan kebebasan eksistensinya dalam hal berbicara. Hal ini dapat diperhatikan melalui kutipan data monolog (D-5) sebagai berikut.

\begin{abstract}
Kau tentu tahu makna sebuah keluarga, sebenarnya dari apa yang sering diocehkan professor sinting itu. Oasis yang dengan sabar menunggu pengembara yang menempuh perjalanan, dan mungkin tersesat, di padang pasir. Pengembara selalu saja membayangkan oasis semacam itu, meskipun sering kali hanya, sayang sekali menemukan oasis lain. (Damono, 2015: 71).
\end{abstract}

Kutipan data kelima tersebut, merepresentasikan bentuk kebebasan yang ditampilkan oleh Soekram berupa monolog dalam cerita. Data ini mengandung esensi kehidupan yang merujuk pada kebebasan perkataan tokoh Soekram yang dapat diperhatikan melalui penggalan kutipan berikut "Kau tentu tahu makna sebuah keluarga, sebenarnya dari apa yang sering diocehkan professor sinting itu" penggalan kutipan ini menggambarkan adanya kebebesan perkataan tokoh utama dalam menanggapi sesuatu yang terjadi sekaligus terkait dengan dirinya. Professor yang dimaksud adalah pengarang, namun dengan bebas tokoh Soekram menyebutnya sinting. Kata "sinting" memiliki arti sedang miring tidak beres pikirannya, dan agak gila. Kata tersebut merupakan katakata makian yang diucapakan Soekram untuk ditujukan kepada pengarang. Hal tersebut menunjukan kebebasan Soekram dalam berbicara 
akibat mengalami konflik batin dengan pengarang sehingga, secara spontan Soekram mengeluarkan bahasa tersebut atas respon dirinya terhadap kondisi psikologis yang membuat dirinya tidak harmonis dengan pengarang.

Keeksistensian hidup tokoh utama dalam novel Trilogi Soekram tersebut, terus menerus berupaya mewujudkannya dalam bentuk perkataan. Olehnya itu, selain perkataan yang merepresentasikan esensi kebebasannya, Soekram juga mengaktualisasikan dalam bentuk perbuatan. Hal ini, dapat diperhatikan melalui kutipan data monolog (D-6) sebagai berikut.

Lha, tapi ini kan hanya cerita, katanya kepada dirinya sendiri sambil merasa agak agak geli. Apalagi konon yang mengarang cerita kan aku sendiri, katanya dalam hati sambil merasa lebih geli lagi. Tapi bagaimanapun ia harus percaya kepada Datuk bahwa memang ada yang namanya Sitti Nurbaya, dan bahwa gadis yang dikatakan mahaelok itu hamil. (Damono, 2015: 173).

Kutipan data keenam tersebut, merepresentasikan bentuk kebebasan yang ditampilkan oleh tokoh utama Soekram berupa monolog dalam cerita. Data ini mengandung esensi kehidupan yang merujuk pada kebebasan bertindak. Hal tersebut dapat diperhatikan melalui penggalan kutipan "Apalagi konon yang mengarang cerita kan aku sendiri” penggalan kutipan ini menggambarkan adanya kebebesan perkataan tokoh utama dalam bertindak atau melakukan sesuatu yang berhubungan dengan dirinya. Hal tersebut menunjukan eksistensi soekram sebagai individu yang bebas bertindak dan bebas dalam melakukan sesuatu, kenapa tidak? Individu yang bereksistensi adalah individu yang bebas dalam segala perbuatan, seperti maksud dari penggalan kutipan tersebut, bahwa soekram yang mengarang ceritanya, jadi mau dibawa kemana terserah. Itulah ciri Soekram sebagai tokoh utama yang bebas memilih dan menentukan nasib ceritannya.
Berikutnya keeksistensian hidup tokoh utama dalam novel Trilogi Soekram juga menggambarkan esensi kebebasan Soekram dalam bertindak atau melakukan sesuatu, sebagaimana yang terlihat pada kutipan data monolog (D-7) sebagai berikut.

Tersentak Soekram pada pikirannya sendiri, dia harus melakukan dua hal yang bertentangan: membantu sepenuhnya perjuangan ujung yang nun jauh di sana itu, tetapi juga harus mampu menyingkirkan Datuk tua idolanya itu agar tak ada lagi segitiga. (Damono, 2015: 94).

Kutipan data ketujuh tersebut, merepresentasikan bentuk kebebasan Soekram yang ditampilkan berupa data monolog dalam cerita. Data ini mengandung esensi kehidupan yang merujuk pada kebebasan bertindak tokoh Soekram yang dapat diperhatikan melalui penggalan kutipan berikut. "Tersentak Soekram pada pikirannya sendiri, dia harus melakukan dua hal yang bertentangan" Kutipan ini menggambarkan adanya kebebesan tokoh utama dalam bertindak atau melakukan sesuatu. Baik sesuatu yang berhubungan dengan dirinya maupun sesuatu yang bertentangan dengan dirinya (paradoks). Hal tersebut dapat memunculkan eksistensi kebebasan Soekram dalam menentukan pilihan serta keputusannya terkait dengan dua hal, apakah Soekram hanya melakukan sesuatu demi menyelamatkan dan mementingkan dirinya sendiri ataukah mengorbankan dirinya demi kepentingan orang banyak melalui perjuangannya. Kata "tersentak" merupakan kata kerja yang berarti tertarik kuatkuat, dan tercabut, serta terbangun atau tersadar tiba-tiba dari tidur, lamunan, dan sebagainya. Hal tersebut sangat berhubungan dengan kondisi dan keadaan yang dialami oleh tokoh Soekram atas situasi dan kondisi perjuangannya atau menyingkirkan seseorang yang menimbulkan konflik batin di antara dirinya dengan seseorang tersebut. 
Selanjutnya keeksistesian Soekram dalam novel Trilogi, juga terus menerus mewujudkannya dalam bentuk tindakan atau perkataan. Sebagaimana yang terlihat pada kutipan data narasi (D-8) sebagai berikut.

Soekram tampaknya sedang menyususun kalimat yang-dia sendiri tak tahu mengapamungkin bisa menguatkan dirinya. (Damono, 2015: 8).

Kutipan data kedelapan tersebut, merepresentasikan bentuk eksistensi yang ditampilkan oleh tokoh utama Soekram berupa data narasi dalam cerita. Data ini mengandung esensi kehidupan yang merujuk pada kebebasan perbuatan tokoh Soekram yang dapat diperhatikan melalui penggalan kutipan berikut "Soekram tampaknya sedang menyusun kalimat yang-dia sendiri tak tahu” Kutipan ini menggambarkan bahwa terkadang manusia secara bebas dan sadar melakukan sesuatu yang tidak dapat dipahami alasan untuk melakukannya. Artinya kebebasan sesorang yang melakukan sesuatu tidak beralasan, sehingga tokoh utama Soekram berusaha secara bebas melakukan sesuatu untuk menyelamatkan dirinya dalam cerita yang diciptakan pengarang. Soekram merasa bahwa dirinya tidak bebas lantaran dia diciptakan oleh pengarang yang tidak memiliki pemahaman dan alasan apa dirinya diciptakan, hal tersebut yang membuat Soekram bebas untuk melanjutkan ceritanya. Soekram berusaha semaksimal mungkin untuk menyusun kalimat-kalimat yang dia sendiri tidak tahu kalimat apa yang mampu menguatkan dirinya tetapi dengan prinsip eksistensinya yang bebas Soekram berusaha keluar dan menyusun kalimat-kalimat yang tidak mungkin menjadi mungkin untuk melanjutkan keberadaan dirinya dalam sebuah cerita demi menyelamatkan eksistensinya sebagai tokoh utama dalam cerita. Kutipan tersebut, menggambarkan adanya eksistensi Soekram selaku tokoh utama yang selalu mempertahankan kebebasanya. Artinya walaupun Soekram tidak memahami apakah kalimat itu bisa menguatkan dirinya atau tidak, tetapi Soekram tetap eksis dalam menyusunnya.

\section{SIMPULAN}

Berdasarkan hasil penelitian dan pembahasan pada bab sebelumnya mengenai kebebasan tokoh utama Soekram dalam novel Trilogi Soekram karya Sapardi Djoko Damono maka ditemukan adanya aspek kebahasaan yang terdiri atas kebebasan dalam wujud perkataan dan kebebasan dalam wujud perbuatan. Aspek perkataan berupa Kalimat Tanya kenapa begitu? Menunjukkan adanya efek keheranan yang dimunculkan melalui proses berpikir Soekram, selanjutnya penggalan kutipan "Ya biar saja" kutipan ini menggambarkan adanya sikap kebebesan perkataan tokoh utama Soekram dalam menanggapi pembicaraan dari lawan tuturnya. prinsip-prinsip kebebasan berupa ucapan dan tindakan yang ditinjau melalui eksistensialisme berupa kecemasan yang terjadi pada diri Soekram sehingga Soekram dengan bebas membuat keputusan di antara alternatifalternatif tentang ke mana arah dan nasibnya di dalam cerita, karena kebebasan, menjadi penentu bagi tindakan-tindakannya untuk menetukan alur ceritanya tanpa ada intervensi pengarang maupun tokoh lain.

\section{DAFTAR PUSTAKA}

Ahmed, H. (1988). Bahasa Sastra, Buku Cetusan Fikiran Ahmed Hasan. Kuala Lumpur: Dewan Bahasa dan Pustaka, Kementerian Pendidikan Malaysia.

Barker, C. (2015). Cultural Studies: Teori \& Praktik. Yogyakarta: Kreasi Wacana.

Damono, D. S. (2015). Trilogi Soekram. Jakarta: PT Gramedia Pustaka Utama.

Fahimsyah dkk. (2013). Eksistensialisme dalam Novel Najla Karya Byar Rufael Sebuah Tinjauan Psikologi Humanistik. Jurnal AlUlum, 1(1), 1-12. 
Heni. (2010). Makna Hidup dalam Dinamika Eksistensi Tokoh Silas Marner dalam Novel Silas Marner Karya George Eliot. Sebuah Pendekatan Psikologi Eksistensialisme. Universitas Diponegoro.

Mendrofa, J. F. (2011). Eksistensialisme Naturalistik: Kajian perspektif Naturalistik terhadap Konsep Eksistensialisme Mengenai Kebebasan dan faktisitas. Universitas Gunadarma.
Saifur, \& Emzir. (2015). Teori dan Pengajaran Sastra. Jakarta: Rajawali Press.

Semi, A. (1998). Kritik Sastra. Bandung: Angkasa.

Suyasa, M. (2004). Pengantar Teori Sastra. Mataram: Universitas Muhammadiyah Mataram Press.

Yunus, M. F. (2011). Kebebasan dalam Filsafat Eksistensialisme Jean Paul Sartre. Jurnal Institut Agama Islam Negeri (IAIN), 11(2), 267-276. 